\title{
Catalytic Energy Production from Municipal Solid Waste Biomass: Case Study in Perlis-Malaysia
}

\author{
Obid Tursunov ${ }^{1, *}$, Jan Dobrowolski ${ }^{1}$, Wojciech Nowak ${ }^{2}$ \\ ${ }^{1}$ Team of Environmental Engineering and Biotechnology, Faculty of Mining Surveying and Environmental Engineering, AGH \\ University of Science and Technology, Krakow, Poland \\ ${ }^{2}$ The Center of Energy, AGH University of Science and Technology, Krakow, Poland \\ *Corresponding author: obidtursunov@gmail.com
}

Received January 03, 2015; Revised February 03, 2015; Accepted February 25, 2015

\begin{abstract}
A study of energy recovery from municipal solid waste was undertaken. The energy content of the solid waste is $2388 \mathrm{kcal} / \mathrm{kg}$. The elemental composition shows that the municipal solid waste contains $53.84 \%$ of carbon and $5.73 \%$ of hydrogen. The energy flow (exothermic and endothermic) and thermal degradation analysis were carried out using calorimeter (model: c2000basic) and ASTM standards respectively. It has been observed that municipal solid waste is less reactive to combustion as compared to coal and biomass, but its reactivity can be improved through pre-treating process so as to reduce noncombustible materials such as oxygen and ash content. Also pyrolysis and gasification can be used to convert MSW to liquid or gaseous fuel. This paper also presents analysis of chemical properties and concentration of raw dolomite, calcined dolomite and zeolite for catalytic cracking of tar and enhancing bio-yield production from technologies such as pyrolysis and gasification of municipal solid waste.
\end{abstract}

Keywords: MSW, biomass, catalyst, energy

Cite This Article: Obid Tursunov, Jan Dobrowolski, and Wojciech Nowak, "Catalytic Energy Production from Municipal Solid Waste Biomass: Case Study in Perlis-Malaysia." World Journal of Environmental Engineering, vol. 3, no. 1 (2015): 7-14. doi: 10.12691/wjee-3-1-2.

\section{Introduction}

The fast population growth, urbanization, living standards will generate a tremendous rate of municipal solid waste (MSW) across the Malaysian municipalities. As a middle-income economy and located in the middle South-East Asia, Malaysia is expected to become a developed country by the year 2020 [1]. According to Vision 2020 and the growing population, the proportion to the increase of solid waste disposal issues related to disposal have become more challenging to dispose of these municipal solid wastes. The disposal practice and tropical climate, as well as inadequate waste management, thus leading to environmental problems in Asian region. Besides, the alterations in consumption patterns with changes in the waste characteristics have resulted in a quantum jump in solid waste generation [2].

With the development of urbanization, more MSW is produced, so it is of great significance and urgency to dispose large quantities of MSW for cities in Malaysia. Currently, landfill is the primary destination of MSW receiving about $80 \%$. Landfill disposal of MSW is becoming environmentally and economically less desirable, because of seepage of toxic decomposition products out of landfill areas, valuable land wastage and increasing transport cost [3]. Incineration of MSW has the merits of minimization innocuously reuse and recycling as an alternative technology, a few MSW incineration facilities for power generation has been established in Malaysia: "Pulau Langkawai”, "Pulau Labuan”, "Cameron Highlands", "Pulau Pangkor" and "Pulau Tioman" [3]. However, the method is not fit for Malaysia because of low heating value of MSW in Malaysia. Furthermore, incineration easily produces toxic gases such as dioxins and hydrogen chloride resulting in secondary pollution to environment. Recently, much attention has been paid to MSW pyrolysis and gasification disposal technology because it is suitable for various fuel feed, can prevent dioxins formation and reduce thermal nitrogen oxides (NOx) formation.

\subsection{Catalysts}

Tar produced in the gasification of coal is deleterious to the operation of downstream equipment, including fuel cells, gas turbines, hot-gas stream cleanup filters, and pressure-swing adsorption systems. Catalytic cracking of tars to smaller hydrocarbons can be an effective means of removing these tars from gas streams and, in the process, generating useful products, e.g., methane gas, which is crucial to operation of molten carbonate fuel cells [4].

The need for on-line cracking of gasification tars is common to many processes involving gas stream cleanup. Aerosol tars are not readily removed from gas streams by conventional means and, as a consequence, often result in plugged filters or fouled fuel cells, turbines, or sorbents. Catalytic cracking of tars to molecular moieties of $\mathrm{C}$, or 
smaller would prevent these problems. As an example, the moving Bourdon (fixed-bed) gasifier by virtue of its efficient countercurrent heat exchange and widespread commercial use may offer the lowest-cost IGCC system, provided tar generation and wastewater contamination can be minimized [4].

The use of catalysts to reduce tar formation in biomass gasification and pyrolysis has also been investigated $[5,6,7]$. Three main groups of catalysts being reported to be successful in removing tars from the producer gas: (1) natural catalysts such as dolomite and zeolite; (2) alkalibased catalysts such as $\mathrm{Li}, \mathrm{Na}, \mathrm{K}, \mathrm{Rb}, \mathrm{Cs}$ and Fr and (3) metal-based catalyst such as nickel catalysts. In the present study dolomite and zeolite were used as catalyst for comprehensive analysis of chemical properties (metal oxides). The use of dolomite for biomass gasification in fluidized bed is attractive since it is a cheap material and exhibits proven catalytic activity and effectiveness to reduce tars both in laboratory-scale gasifiers and pilot plants [8]. Dolomite is more effective than zeolite as catalyst although is less resistant against attrition and generates more particulates in the product gas $[9,10]$. Calcined dolomite has shown even better efficiency for increasing hydrogen content as compared to raw dolomite [11]. Several experimental works on the gasification of woody biomass in fluidized bed have reported the benefits of using dolomite on tar depletion [12,13,14]. Narvaez et al. [12] used calcined dolomite (3 wt.\%) mixed with the processed biomass and found that the tar content decreased from 10 to $4 \mathrm{~g} / \mathrm{Nm} 3$. This reduction is in agreement with data reported by Miccio et al. who revealed a tar reduction up to $50 \%$ by using this catalyst as bed material. A former study by Gil et al. [13] concluded that with a 15-30 wt.\% of calcined dolomite in bed, tar contents below $1 \mathrm{~g} / \mathrm{Nm} 3$ could be obtained. However, zeolites are crystalline materials with ordered pore structures that are widely used as industrial catalysts. They are particularly important in oil refining, where the outcome of chemical transformations is strongly influenced by the pore topology of the zeolite catalyst. In a review, Smit and Theo [15] argue that this so-called shape selectivity can be rationalized using a straightforward thermodynamic analysis of how pore topology affects the free energies of formation of the reactants, intermediates and products. Despite the need for drastic simplifications, the approach can explain experimental observations and even guide the search for zeolite structures optimized for specific catalytic applications.

\subsection{Laser Biotechnology for more Efficient Production of Bio-Energy}

One of the promising alternatives to meet the increasing demands of the human population and the new model of consumption for energy sources is the production of bioenergy from plant biomass.

According to Dobrowolski et al. [16], - results of experiments showed that application of optimal algorithm of laser photostimulation increased plant biomass production in deteriorated areas. Empirically selected method of stimulation could increase efficiency of phytoremediation by increase uptake of trace metals and biodegradation of xenobiotics and biogens from contaminated water and soil. Application of laser biotechnology could be used in environmental engineering technologies in the bio-based green economy, following the concept of sustainable development.

Application of laser stimulation of different species of plants, soil bacteria and fungi in environmental biotechnology was initiated by Dobrowolski in 1978, for the optimization of bioremediation processes, e.g. removal of pollutants from sewage and soil reclamation as well as for increase of biomass production by plants cultivated in polluted soils $[17,18]$.

The proper time of exposure to selected wavelength and energy density of coherent light was able to stimulate the growth rate of plants cultivated in suboptimal environmental conditions and reclamation of deteriorated regions, the biomass production as well as bioremediation of selected toxic metals from contaminated soil and better waste water treatment in hydro-botanic plants [19].

The increase of the biomass production of energy plantations as a result of laser photostimulation (sources of coherent light) of plants in deteriorated areas, e.g. on contaminated soil, as well as the application of similar method to increase biomass production in hydro-botanic wastewater treatment plants, the promotion low carbon energy production and the sustainable development could be recommended for large-scale application. Thus, application of eco-friendly laser biotechnology could contribute both to better bioremediation of contaminated land and groundwater as well as for the development of biomass production as a source of renewable bio-energy and for creating green jobs.

\section{Materials and Methods}

This research methodology consists of sampling selection method, sorting procedure and laboratory analysis to identify proximate and ultimate analysis of the MSW accommodated at Padang Siding landfill, Perlis, Malaysia. Generally, there are two formal types of sampling and analysis methods based on ASTM D 52315292 [20].

Accordingly, research methodology will help for management categories in order to improve MSW treatment routes by identifying recycling opportunities, promoting waste abatement efforts or isolating specific fractions as well.

\subsection{Method for MSW Characterization}

\subsubsection{MSW Sampling}

The procedure was applied for collecting the representative MSW. Base on the American Society for Testing and Materials (ASTM), the sampling was pick up of the garbage bag from waste landfill at Padang Siding, Arau, Perlis, Malaysia which is usually an amount of 15 or $20 \mathrm{~kg}$ and investigated at the research laboratory under School of Environmental Engineering, University Malaysia Perlis (UniMAP), Kangar, Perlis, Malaysia. Next, the waste was separated according to the selected classification and the MSW samples were a mixture of seven different components of wood, kitchen garbage, plastic bag, solid plastic, textile, glass and ferrous materials. Each category was weighted by using a weight 
balance and the materials were discarded after recording the data.

\subsection{Proximate Analysis of MSW Sample}

Proximate analysis consist of moisture content, volatile matter, ash content and content of fixed carbon and determination of calorific value. Moisture content, volatile matter, ash content and fixed carbon determined by put the selected sample to different range of the temperature, between $100^{\circ} \mathrm{C}$ to $950^{\circ} \mathrm{C}$. The laboratory methods to measuring the proximate analysis of MSW samples in this research project were carried out based on ASTM standard. This standard determine the condition of lab analysis such moisture, volatile matter, ash and fixed carbon content.

\subsubsection{Moisture Content}

The percent moisture of the MSW samples was determined by weighting of the samples into dish and drying the samples in an oven at $105^{\circ} \mathrm{C}$ for four hours after which it was cooled and then reweighted to constant weight. The same methodology for determination of moisture content has been used by Maoyun, et al. [21]. The percent moisture content was calculated as a percentage loss in weight before and after drying [20,22,23].

$$
\begin{aligned}
& \text { Moisture content }= \\
& {\left[\begin{array}{l}
(\text { Wet Weight }- \text { Dry Weight }) \\
\text { /Wet weight }
\end{array}\right] \times 100(\%)}
\end{aligned}
$$

\subsubsection{Volatile Matter Content}

The volatile matter content was determined by the method of ignition of the sample at $950^{\circ} \mathrm{C}$. The samples of MSW material used in the moisture content determination were prepared in duplicate and $5 \mathrm{~g}$ of MSW placed in a crucible. The crucible with its content was placed in the muffle furnace at a temperature of $950^{\circ} \mathrm{C}$, and heated for precisely seven minutes [20], timed with a stop watch. The similar experiments for moisture content determination have been done by a few scholars such as Amin and Yang [22] and Edema et al. [23]. After combustion, the crucible was then removed from the furnace and cooled. After cooling the crucible with its sample content were weighted accurately and volatile matter calculated as:

$$
\begin{aligned}
& \text { volatile matter }=\text { loss in weight } \times 100 / \\
& \text { weight of sample }-\{\% \text { moisture }\}
\end{aligned}
$$

\subsubsection{Ash and Fixed Carbon Content}

Ash content of waste is the non combustible residue left after the waste is burnt up. Analysis include of MSW sample were taken in duplicate of $5 \mathrm{~g}$ each and ignited to heat up to $400^{\circ} \mathrm{C}$ with gradual increase in temperature of the muffle furnace to $750^{\circ} \mathrm{C}$ for one hour [20,22,23]. The dish was removed from the muffle furnace. The dish was allowed to cool down before the residue was weighted. The ash content of the sample was calculated as:

$$
\begin{aligned}
& \% \text { ash }=\text { weight of sample } \times 100 \\
& / \text { weight of the sample }
\end{aligned}
$$

Fixed carbon defined by carbon found in the material which is left after volatile test. Fixed carbon is determined by removing the mass of volatiles from the original mass of the sample:

$$
\begin{aligned}
& \text { Fixed Carbon }(\text { Wt } \% \text { wet basis })= \\
& 100-\left(\begin{array}{l}
W t \% \text { moisture content } \\
+W t \% \text { Ash }+W t \% \text { volatile matter }
\end{array}\right)
\end{aligned}
$$

\subsubsection{Calorific (Energetic) Value}

Determination of the heating value can be investigated either experimentally or by using mathematical models. Experimental determination by using a bomb calorimeter utilize a sample size of $1 \mathrm{~g}$ or either $2 \mathrm{~g}$ which is inadequate to account for the vast variance in MSW composition, thus requiring bigger sample size [24,25]. Furthermore, the experimental method is tedious and also requires technical skills in handling the equipment and the combustion by products as well. As for the mathematical models, they were created to avoid over reliance on lengthy experimental technique. In this research paper, the heating value was determined by using a bomb calorimeter (Model: C 2000 Basic- IKA co, Germany).

\subsection{Ultimate Analysis of MSW Sample}

Ultimate analysis was used to determine the CHNSand- O content in MSW sample by using a CHNS/O Elemental Analyzer. Such analysis presents the weight percent of carbon, hydrogen, oxygen, nitrogen, and sulphur in the sample simultaneously, and the weight percent of oxygen is determined by difference.

A schematic diagram of the PerkinElmer 2400 Series II CHNS/O Elemental Analyzer is shown in Figure 1. The $\mathrm{CHN}$ and CHNS modes are based on the classical PreglDumas method where samples are combusted in a pure oxygen environment, with the resultant combustion gases measured in an automated fashion. The 2400 Series II system is comprised of four major zones: 1) Combustion Zone, 2) Gas Control Zone, 3) Separation Zone, 4) Detection Zone.

In the Combustion Zone, samples encapsulated in tin or aluminum vials are inserted automatically from the integral 60-position auto-sampler or manually using a single-sample auto injector.

In the presence of excess oxygen and combustion reagents, samples are combusted completely and reduced to the elemental gases $\mathrm{CO}_{2}, \mathrm{H}_{2} \mathrm{O}, \mathrm{N}_{2}$ and $\mathrm{SO}_{2}$. Users have the flexibility of optimizing static and dynamic combustion conditions to meet the specific sampling need of their laboratory. The combustion products are then passed to the Gas Control Zone of the 2400 Series II.

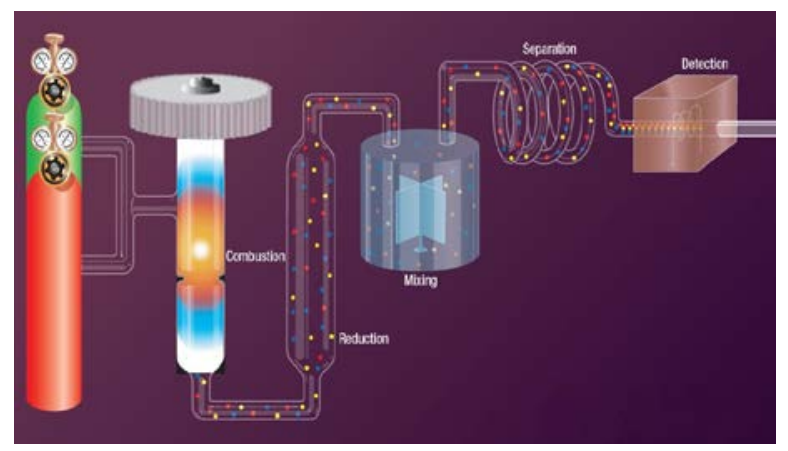

Figure 1. 2400 Series II CHNS/O Schematic. (source: www.perkinelmer.com) 
Gases are captured in the mixing chamber of the Gas Control Zone. Here, gases are rapidly mixed and precisely maintained at controlled conditions of pressure, temperature and volume. By controlling the product gases from combustion/pyrolysis to the same exact conditions (pressure, volume and temperature) for every run, outside influences (barometric pressure changes, altitude) are eliminated. The combustion process is separated from the column and detector which gives the flexibility of varying combustion conditions in the same series of runs without influencing separation and detection and the gases are mechanically homogenized therefore providing precision and accuracy.

After homogenization of product gases, the mixing chamber is depressurized through a column in the Separation Zone of the instrument. The separation approach used is a technique known as Frontal Chromatography.

As the gases elute, illustrated in Figure 1, they are measured by a thermal conductivity detector in the Detection Zone of the analyzer. Since measurements in this design are made as stepwise changes from the carrier gas baseline, the variations associated with the quantification of peak signals in other $\mathrm{CHNS} / \mathrm{O}$ analyzers is eliminated.

\subsection{Catalysts}

Natural raw dolomite was collected from Padang Besar, Perlis, Malaysia. In the next step, natural dolomite was ground by using crusher and sieved, the particle with a size of $0.2-0.5 \mathrm{~mm}$ was calcined in muffle oven under temperatures: $800^{\circ} \mathrm{C}$ for 5 hour and $950^{\circ} \mathrm{C}$ for 3 hour in order to make a comparison, to determine, to detect an appropriate calcined dolomite for gas production in pyrolysis process, and also to carry study in the field of dolomite calcinations. The calcinations of catalyst dolomite under different temperature and list of catalyst used in pyrolysis process were shown in Table 1. Calcined dolomite and natural dolomite were used as catalyst in this study. Nevertheless, another type of catalyst "Zeolite” was also used in this study to make a comparison with dolomite for gas production in pyrolysis process. The Xray diffraction of natural, calcined dolomite and zeolite evaluated by using X-ray fluorescence (XRF) spectrometer (model: PW 4030).

Table 1. Calcinations of dolomite under different temperatures and catalyst used in the pyrolysis process.

\begin{tabular}{|c|c|}
\hline Name of catalyst & Calcinations temperature and time \\
\hline Raw Dolomite & - \\
\hline Calcined dolomite & $800^{\circ} \mathrm{C}$ and $5 \mathrm{~h}$ \\
\hline Calcined dolomite & $950^{\circ} \mathrm{C}$ and3h \\
\hline Zeolite & - \\
\hline
\end{tabular}

\subsubsection{Minipal 4 X-ray Fluorescent (XRF) Spectrometer}

X-ray Fluorescent (XRF) Spectrometer is a nondestructive analytical technique used to identify and determine the concentration of elements present in solid, powdered and liquid samples. XRF is capable of measuring elements from Beryllium (BE) to Uranium (U), and beyond at trace levels and up to $100 \%$. The XRF spectrometer measures the individual component wavelengths of the fluorescent emission produced by a sample when irradiated with X-rays. It applications include: process and quality control, recycling, incoming materials inspection and identification of unknown samples. Methodology for sampling analysis is shown in Figure 2. Accordingly, it demonstrates how sample deliver to the X-ray Spectrometer and main applications, such as sample changer, measuring positions, silicon drift detector, filters and tube, that are important parameters to identify sample chemical compositions.

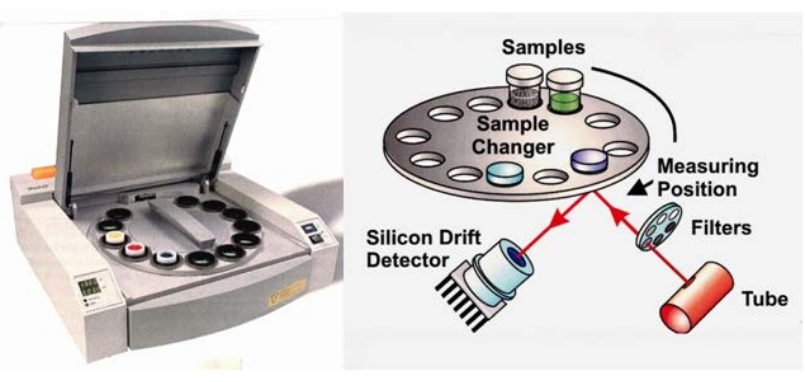

Figure 2. Minipal 4 X-ray Fluorescent (XRF) Spectrometer and analysis method

\section{Results and Discussions}

\subsection{Results from Sampling}

The investigation took place for two months. Obtained result from sorting process and quantity of each individual component of the MSW at Padang Siding landfill is shown in Figure 3.

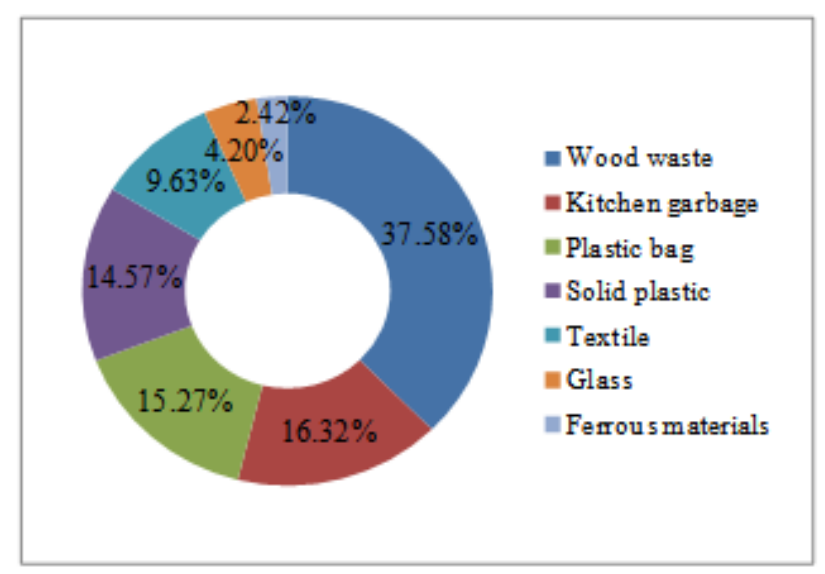

Figure 3. Municipal solid waste composition

As Figure 3. indicates MSW such as, wood and kitchen waste, plastic bag and solid plastic make up the largest fraction of generated waste in Padang Siding landfill. Top seven individual materials were most prevalent in the Padang Siding disposed waste stream included of wood waste $(37.58 \%)$, kitchen garbage (16.32\%), plastic bag (15.27\%), solid plastic (14.57\%), textile (9.63\%), glass $(4.20 \%)$ and ferrous materials (2.42\%). The high percentage of wood waste can be explained by increasing the demand on wood by households to use in a different area of building and for daily use as well. In addition, a few factories are located in Perlis, for instance high volume of wood, plastic with glass and ferrous metals were sugar factory wastes.

This is expected, increasing the population, migration and also industrialization during the past few years were 
the main reason for increasing the quantity of MSW. Glass and ferrous materials had the small fraction of MSW in this landfill. High percentage of recyclable components show the landfill in Padang Siding has potential for provide the recovery facilities, for example "pyrolysis techniques". The recovery process can be considered as one of the acceptable methods to handle and decrease the high volume of recyclable materials.

\subsection{Results from Proximate and Ultimate Analysis}

Proximate analysis involves determination of moisture content, volatile matter, ash content, fixed carbon and also calorific value. The analysis was according to ASTM method. And Ultimate analysis demonstrates determination of chemical characteristics of MSW sample. Results from proximate and ultimate analysis are shown in Table 2.

Table 2. Proximate and Ultimate analysis of MSW

\begin{tabular}{|c|c|c|c|}
\hline \multicolumn{2}{|c|}{ Proximate Analysis } & \multicolumn{2}{c|}{ Ultimate Analysis } \\
\hline Moisture & $16.9(\mathrm{wt} \%)$ & C (carbon) & $53.84(\mathrm{wt} \%)$ \\
\hline Volatile & $55.1(\mathrm{wt} \%)$ & H (hydrogen) & $5.73(\mathrm{wt} \%)$ \\
\hline Fixed carbon & $8(\mathrm{wt} \%)$ & O (oxygen) & $32.93(\mathrm{wt} \%)$ \\
\hline Ash & $20(\%)$ & $\mathrm{N}$ (nitrogen) & $1.68(\mathrm{wt} \%)$ \\
\hline Calorific value & $2388(\mathrm{kcal} / \mathrm{kg})$ & $\mathrm{S}$ (sulfur) & $0.87(\mathrm{wt} \%)$ \\
\hline
\end{tabular}

Table 2 shows that the proximate and ultimate analysis of MSW used in this research. The table shows moisture content (16.9 wt\%) and fixed carbon (8 wt\%). The moisture content is measure with the amount of water lost from materials upon drying to a constant weight. It is directly affected by chemical and physical properties of material which enable it to absorb the exiting water in the environment. Fixed carbon is the carbon remaining on surface as charcoal. Table 2 shows processed MSW has volatile matter content (55.1 wt\%) and ash content (20 wt\%); both parameters have influence on the pyrolysis characteristics. The MSW is easier to ignite and to gasify than coal apparently due its volatile matter although the pyrolysis is expected to be more rapid and difficult to control. The calorific value (heating value) of MSW was obtained to be $2388 \mathrm{kcal} / \mathrm{kg}$ based on the bomb calorimeter test. The results of ultimate analysis that was investigated by CHNS/O (Perkin Elmer), elemental analyzer was also shown in Table 2. Maoyun et al. [21] indicated the results obtained from the proximate and ultimate analysis of MSW by using CHNS/O elemental analyzer.

\subsection{X-ray Patterns Results}

The surface characteristics and X-ray patterns of the catalysts are listed in Table 3 and Figure 4 - Figure 7 respectively.

Table 3. Surface characteristics of the raw dolomite, dolomite calcined at $800^{\circ} \mathrm{C}$ for $5 \mathrm{~h}$, dolomite calcined at $950^{\circ} \mathrm{C}$ for $3 \mathrm{~h}$ and zeolite

\begin{tabular}{|c|c|c|c|c|c|c|c|c|c|}
\hline \multicolumn{10}{|c|}{ Raw dolomite } \\
\hline Chemical component & $\mathrm{CaO}$ & $\mathrm{MgO}$ & $\mathrm{Fe}_{2} \mathrm{O}_{3}$ & $\mathrm{Al}_{2} \mathrm{O}_{3}$ & $\mathrm{CuO}$ & $\mathrm{SrO}$ & $\mathrm{TiO}_{2}$ & $\mathrm{CeO}$ & $\mathrm{MnO}$ \\
\hline Conc Unit (\%) & 97.19 & 1.6 & 0.48 & 0.2 & 0.13 & 0.097 & 0.09 & 0.09 & 0.06 \\
\hline \multicolumn{10}{|c|}{ Calcined dolomite at $800^{\circ} \mathrm{C}$ for $5 \mathrm{~h}$} \\
\hline Chemical component & $\mathrm{CaO}$ & $\mathrm{MgO}$ & $\mathrm{RuO}_{2}$ & $\mathrm{Fe}_{2} \mathrm{O}_{3}$ & $\mathrm{Nd}_{2} \mathrm{O}_{3}$ & $\mathrm{TiO}_{2}$ & $\mathrm{CuO}$ & $\mathrm{SrO}$ & $\mathrm{MnO}$ \\
\hline Conc Unit (\%) & 84.75 & 14.2 & 0.39 & 0.305 & 0.081 & 0.064 & 0.057 & 0.038 & 0.032 \\
\hline \multicolumn{10}{|c|}{ Calcined dolomite at $950^{\circ} \mathrm{Cfor} 3 \mathrm{~h}$} \\
\hline Chemical component & $\mathrm{CaO}$ & $\mathrm{MgO}$ & $\mathrm{Pr}_{2} \mathrm{O}_{3}$ & $\mathrm{RuO}_{2}$ & $\mathrm{SO}_{3}$ & $\mathrm{Fe}_{2} \mathrm{O}_{3}$ & $\mathrm{TiO}_{2}$ & $\mathrm{CuO}$ & $\mathrm{V}_{2} \mathrm{O}_{5}$ \\
\hline Conc Unit (\%) & 83.40 & 15.5 & 0.68 & 0.31 & 0.27 & 0.22 & 0.067 & 0.05 & 0.04 \\
\hline \multicolumn{10}{|c|}{ Zeolite } \\
\hline Chemical Component & $\mathrm{SiO}_{2}$ & $\mathrm{CaO}$ & $\mathrm{TiO}_{2}$ & $\mathrm{Cr}_{2} \mathrm{O}_{3}$ & $\mathrm{MnO}$ & $\mathrm{Fe}_{2} \mathrm{O}_{3}$ & $\mathrm{CuO}$ & $\mathrm{ZrO}_{2}$ & $\mathrm{PdO}$ \\
\hline Conc Unit (\%) & 98.38 & 0.39 & 0.1 & 0.024 & 0.003 & 0.094 & 0.069 & 0.03 & 0.17 \\
\hline
\end{tabular}

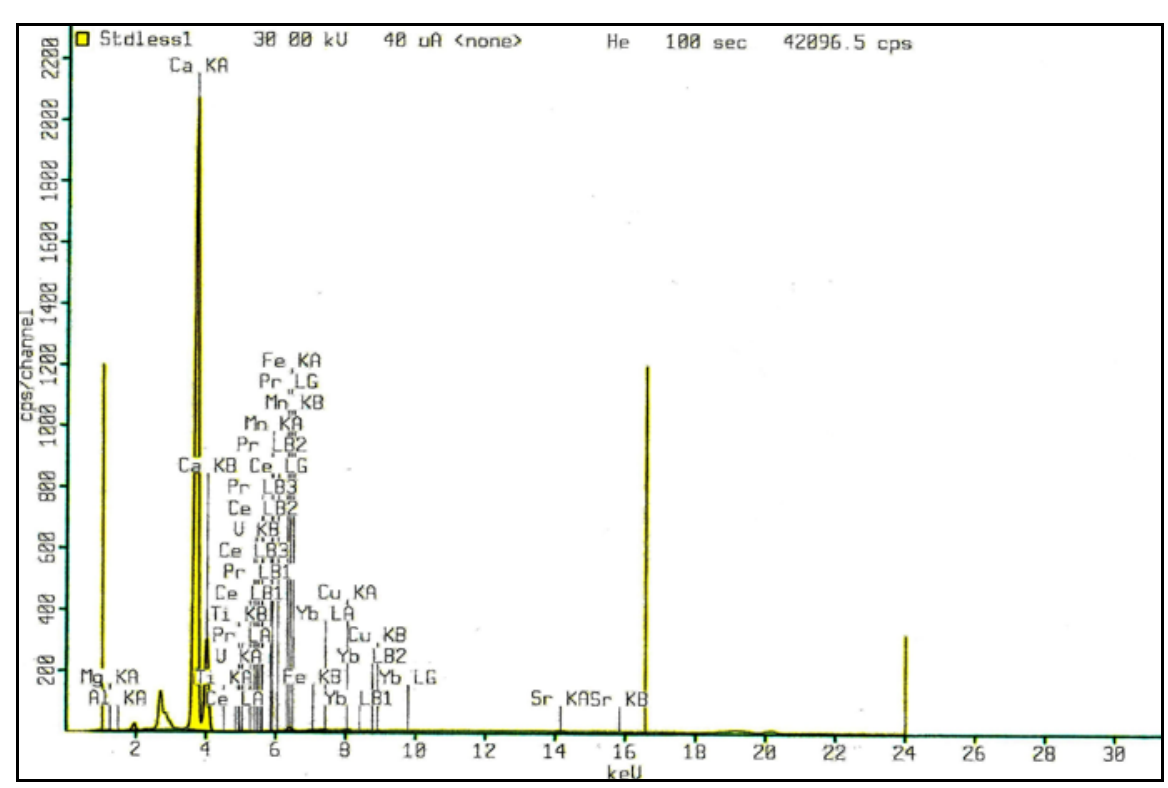

Figure 4. X-ray patterns of dolomite 


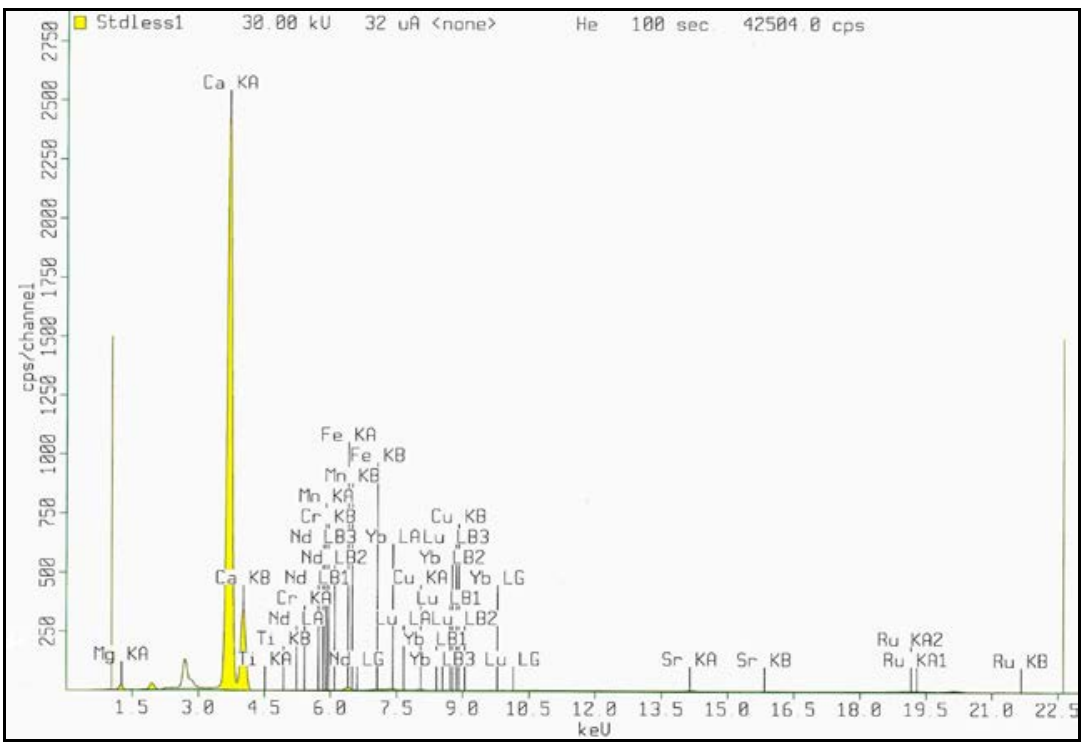

Figure 5. X-ray patterns for calcined dolomite $\left(800^{\circ} \mathrm{C} / 5 \mathrm{~h}\right)$

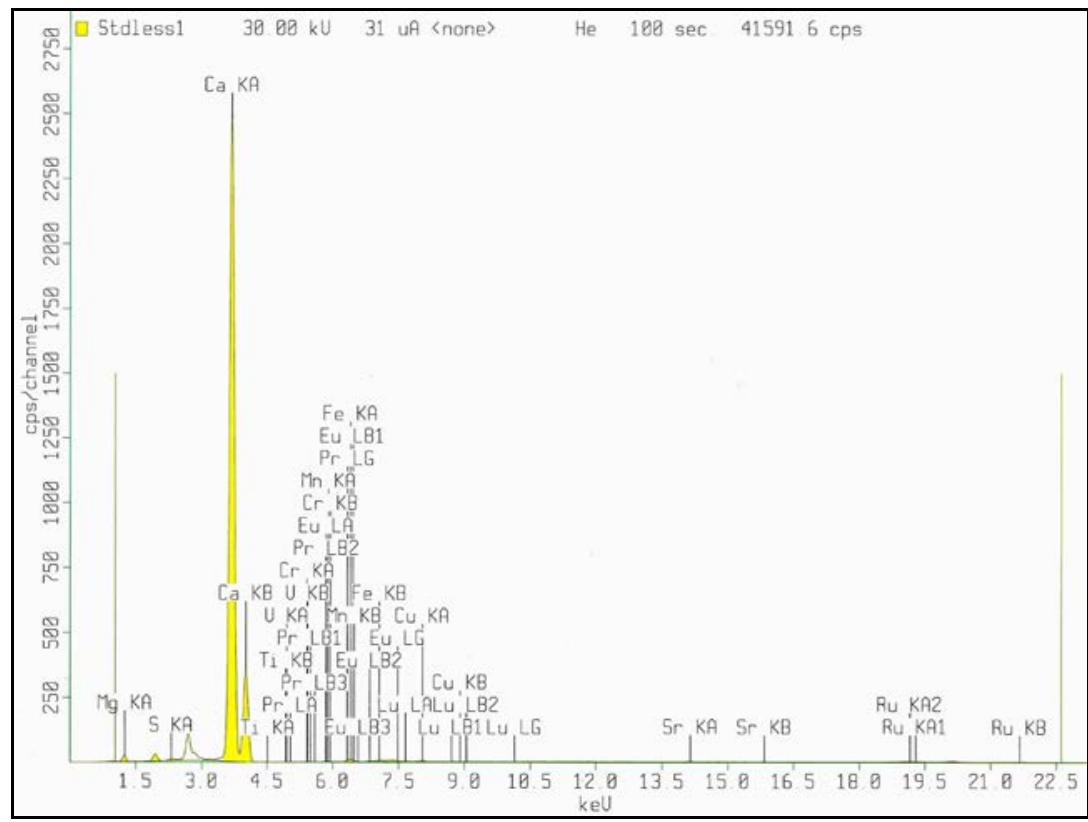

Figure 6. X-ray patterns for calcined dolomite $\left(950^{\circ} \mathrm{C} / 3 \mathrm{~h}\right)$

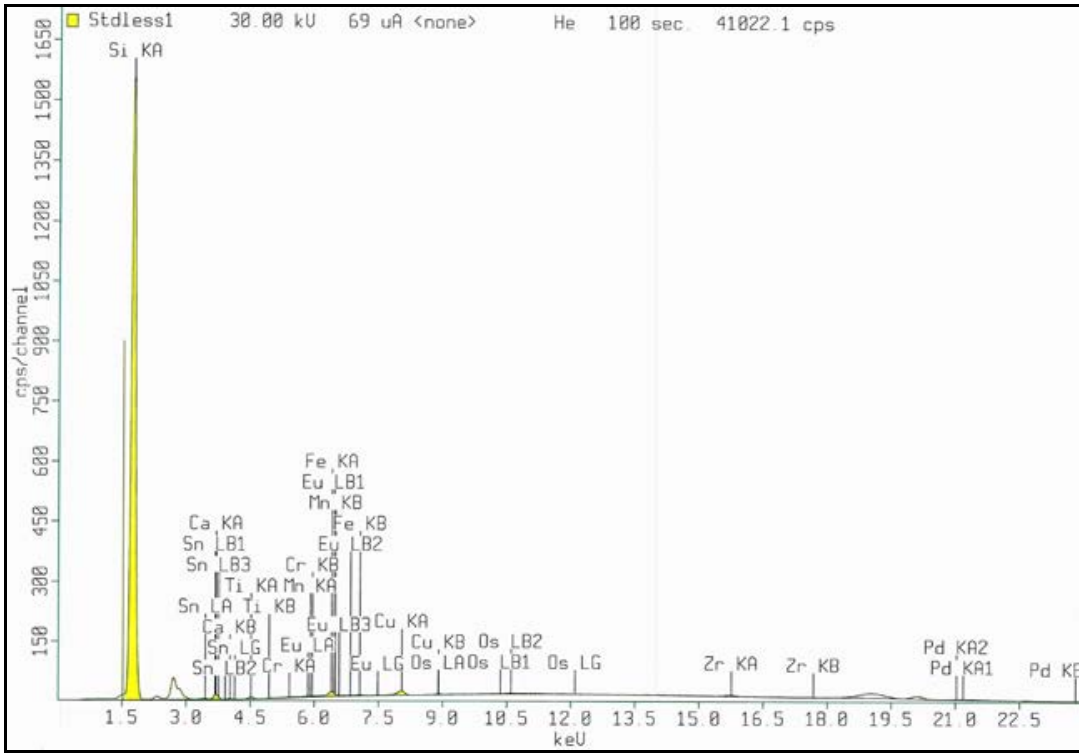

Figure 7. X-ray patterns of Zeolite 
Figure 4, Figure 5, Figure 6, Figure 7. and Table 3. Indicate that $\mathrm{CaO}$ and $\mathrm{MgO}$ were the main components in dolomite that have been calcined for 5 and 3 hours at $800^{\circ} \mathrm{C}$ and $950^{\circ} \mathrm{C}$ respectively, while the greater concentration for $\mathrm{SiO}_{2}$ (98.38\%) was observed. Calcined dolomite under $950^{\circ} \mathrm{C}$ for 3 hour can significantly balance calcium oxide and magnesium oxide composition that are necessary in pyrolysis or in gasification processes for tar cracking and bio-yield production. Research by Caputo and Pelagagge [26] showed that calcinations at high temperatures $\left(900-950^{\circ} \mathrm{C}\right)$ for $3-3.5$ hours improves the quality of the product gas and diminishes significantly the tar yield.

According to the results of all types of dolomites calcination, $\mathrm{CaO}$ and $\mathrm{MgO}$ are the significant chemical components for catalytic pyrolysis and gasification and for tar cracking, as well as they can give higher gas yields during process. Research investigation by Mahishi and Goswami [27] has also illustrates that calcined dolomite basically consists of $\mathrm{CaO}, \mathrm{MgO}$ and with a low concentration unit of other oxides compounds. These two compounds $\mathrm{CaO}$ and $\mathrm{MgO}$ are the vital factors which lead to production of high content of combustible bio-energy (bio-gas) and suitable chemical compounds for tar cracking. Zeolite with higher content of silicon affect the production of liquid from pyrolysis process [28].

\section{Conclusions and Recommendations}

This paper presents the municipal solid waste characterization of Perlis state of Malaysia. The proximate analysis of municipal solid waste show that, the waste contains more than $50 \%$ and $5 \%$ of carbon and hydrogen respectively which may contribute to high calorific value of Perlis municipal solid waste. The ultimate analysis showed that average amount of nitrogen and sulfur were small.

The energy content of waste determined by bomb calorimeter is about $9.998 \mathrm{Mj} / \mathrm{kg}$ this was about $30 \%$ of energy contained in coal and $60 \%$ of energy contained in biomass. Therefore, municipal solid waste has a good potential to be used as a fuel.

Moreover, catalysts as raw dolomite, calcined dolomite $\left(800^{\circ} \mathrm{C} / 5 \mathrm{~h}\right.$ and $\left.950^{\circ} \mathrm{C} / 3 \mathrm{~h}\right)$ and zeolite have been widely studied. It is suggested, that calcined dolomite has an efficiency to eliminate tar from reactors and enhance bioyields (e.g. bio-gas) production from the process of pyrolysis or gasification. Regarding to zeolite, it is a catalyst for improving the quantity and quality of bio-fuel yield from pyrolysis technology, but it is not effective catalyst for tar cracking.

There are real perspectives of supplementation of municipal solid waste by laser-stimulated biomass production in areas out of use including reclamation places of deposition of wastes. Linkage between more efficient management of the natural environment with progress in production of bioenergy from renewable sources could contribute to development of sustainable labor market.

\section{Acknowledgement}

We would like to express our profound gratitude to Prof. Khairul Nizar, Dr. Irnis Azura, Dr. Khairuddin Md Isa, Dr. Ong Soon An and respected technicians of the laboratory of Renewable Energy, Faculty of Environmental Engineering of the University Malaysia Perlis for their kind and professional assistance with this project.

\section{References}

[1] A. Mustapha, Mahathir's Vision 2020: Towards a Developed and Industrialized Society. Malaysia Entrepreneurship. 1996, pp. 1119.

[2] C. Visvanathan, J. Trankler, P. Kuruparan, B. F. A. Basnayake, C. Chiemchaisri, J. Kurian, Z. Gonming, Asian Regional Research Programme on Sustainable Solid Waste Landfill Management in Asia. Proceeding Sardinia 2005. Tenth International Waste Management and Landfilling Symposium S. Margherita di Pula Cagliari, Italy. 3-7 Oct.

[3] O.Tursunov, Production of catalytic and non-catalytic gases from pyrolysis of municipal solid waste (MSW). M.Sc. Thesis. University Malaysia Perlis (UniMAP): Malaysia, 2012.

[4] R.S.Timpe, B.C. Young, A comparison of zeolite and dolomite as gasification tar-cracking catalyst. Energy and Environment Research Center. University of North Dakota. 1995, ND 582029018.

[5] T. Milne, R. Evans, Biomass gasifier "Tars": their nature, formation, and conversion. National Renewable Energy Laboratory. 1998, pp. 253-257. NREL/TP-570.

[6] M. Asadullah, T. Miyazawa, S. Ito, K. Kunimori, M. Yamada, Tomishige Keiichi, Catalyst development for the gasification of biomass in the dual-bed gasifier. Appl Catal A Gen. 255 (2) (2003) 169-180.

[7] P. Weerachanchai, M. Horio, C. Tangsathitkulchai, Effects of gasifying conditions and bed materials on fluidized bed steam gasification of wood biomass. Biores Technol. 100 (3) (2009) 1419-1427.

[8] A. Olivares, M.P. Aznar, M.A. Caballero, J. Gil, E. Francés, J. Corella, Biomass gasification: produced gas upgrading by in-bed use of dolomite. Indus Eng Chem Res. 36 (12) (1997) 5220-5226.

[9] O. Tursunov, A comparison of catalysts zeolite and calcined dolomite for gas production from pyrolysis of municipal solid waste (MSW). Elsevier Applied Science. Science Direct. J. Ecological Engineering. 69 (2014) 237-243.

[10] O.Tursunov, K. Isa, S. Ong, Review paper of catalyst (dolomite) analysis for MSW pyrolysis (gasification). International Postgraduate Conference on Engineering (IPCE). Perlis, Malaysia, 2011.

[11] G. Hu, S. Xu, S. Li, C. Xiao, S. Liu, Steam gasification of apricot stones with olivine and dolomite as downstream catalysts. Fuel Process Technol. 87 (5) (2006) 375-382.

[12] I. Narvaez, A. Orio, M.P. Aznar, J. Corella, Biomass gasification with air in an atmospheric bubbling fluidized bed. Effect of six operational variables on the quality of the produced raw gas. Indus Eng Chem Res. 35 (7) (1996) 2110-2120.

[13] J. Gil, M.A. Caballero, J.A. Martin, M.P. Aznar, J. Corella, Biomass gasification with air in a fluidized bed: effect of the inbed use of dolomite under different operation conditions. Indus Eng Chem Res. 38 (11) (1999) 4226-4235.

[14] F. Miccio, B. Piriou, G. Ruoppolo, R. Chirone, Biomass gasification in a catalytic fluidized reactor with beds of different materials. Chem Eng J. 154 (1-3) (2009) 369-374.

[15] B. Smit, L.M. Theo, Towards a molecular understanding of shape selectivity. J. Nature. 451 (2008) 671-678.

[16] J.W. Dobrowolski, M. Sliwka, R. Mazur, Laser biotechnology for more efficient bioremediation, protection of aquatic ecosystems and reclamation of contaminated areas. J. Chem Technol Biotechnol. 87 (2012). 1354-1359.

[17] J.W. Dobrowolski, Perspectives of application of laser biotechnology in management of the natural environment. Polish Journal of Environmental Studies. 10 (2000) 7-9.

[18] J.W. Dobrowolski, Ecotoxicology, human ecology, laser biotechnology in primary prevention of environmental health hazard. J. Przeglad Lekarski. 58 (2001) 7.

[19] J.W. Dobrowolski, B. Rozanowski, A. Zielinska-Loek, M. Sliwka, K. Gowin, R. Mazur, P. Lewicki, A. Zakrewska, A. Slazak, 
Perspectives of application of laser biostimulation for more bioremediation of soil and wastewater. Intl Conference on Bioremediation of Soil and Groundwater. Politechnika Slaska, Krakow, 2004, p 133-148.

[20] ASTM, Standard Test method for Determination of the Composition of Unprocessed MSW, American Society for Testing and Materials. US, 1998, 5231-5292.

[21] H. Maoyun, B. Xiao, L. Shiming, H. Zhiquan, G. Xianjun, L. Siyi, Y. Fan, Syngas production from pyrolysis of municipal solid waste (MSW) with dolomite as downstream catalysts. Journal of Analytical and Applied Pyrolysis. 87 (2010) 181-187.

[22] K. Amin, G.S. Yang, Identification of the MSW Characteristics and Potential of Plastic Recovery at Bakri Landfill. Journal of Sustainable Development. 5 (2012) 11-17.

[23] M.O. Edema, V. Sichamba, F.W. Ntengwe, (2012). Solid Waste Management-Case Study of Ndola, Zambia. International Journal of Plant, Animal and Environmental Sciences. 2 (2012) 248-255.
[24] M. Reilly, K. Churney, D. Kirklin, A. Ledford, E. Comalski, An oxygen flow calorimeter for kilogram-size samples of MSW, J. Resour Conserv. 8 (1982) 147-157.

[25] P. Vessilind, W. Martello, B. Gullett, Calorimeteric of refuse derived fuels, J. Waste Mgmt Res, 4 (1981) 89-97.

[26] A.C. Caputo, P.M. Pelagagge, RDF production plants: I Design and costs. Applied Thermal Engineering. 22 (2002) 423-437.

[27] M.R. Mahishi, D.Y. Goswami, An experimental study of hydrogen production by gasification of biomass in the presence of CO2 sorbent. International Journal Hydrogen Energy. 32 (2007) 2803-2808.

[28] M. Grosso, M. Giugliano, G. Lonati, L. Rigamonti, Energy recovery from MSW: assessment of practicable options. In: Proceedings of the International Symposium of SanitaryEnvironmental Engineering, Taormina, 2004, 23-26 June. 